МОЙСЕСНКО В. І., д-р техн. наук, професор ${ }^{1}$, БУТЕНКО В. М., канд. техн. наук, доцент ${ }^{1}$, ЧУБ С. Г., канд. техн. наук, доцент ${ }^{2}$, ГОЛОВКО О. В., канд. техн. наук, доцент ${ }^{1}$ ( ${ }^{1}$ Український державний університет залізничного транспорту) ( ${ }^{2}$ ДП «Харківстандартметрологія»)

\title{
Проблеми випробувань комплексів технічних засобів керування та регулювання руху поїздів
}

У статті досліджено проблеми, які виникають під час випробувань комплексів технічних засобів керування та регулювання руху поїзів. Зокрема відзначені важливість і складність оцінювання показників функційної безпечності та надійності, а також високий рівень існуючих вимог. Проаналізовано зміст нормативного документа ДСТУ 4178-2003, у якому визначені вимоги до зазначених показників. Виявлені певно негативні особливості иьього документа, які суттєво ускладнюють формування об'єктивних експертних оцінок. Сформульовано пропозииї щуодо усунення циих негативів, зокрема перехід до застосування нових, сучасних нормативних документів.

Ключові слова: випробування, функиійна безпека, надійність.

\begin{abstract}
Вступ
Теорія безпеки на залізничному транспорті вчасна та важлива частина сучасних досліджень надійності та безпечності [1]. Безпечність спеціалізованих комп'ютерних систем успішно вивчається студентами другого освітнього рівня [2]. Методи підвищення надійності програмного забезпечення інформаційних систем розглянуті в роботі [3]. Достатньо висвітлені методики і кількісна реалізація розрахунку показників надійності та безпечності [4-7].

Програмою розвитку залізничного транспорту передбачено проведення модернізації технічних засобів систем керування рухом поїздів 3 використанням сучасних досягнень мікропроцесорної техніки. Наявність значного рівня зношеності основних засобів і необхідність проведення дуже масштабних обсягів робіт з модернізації потребують проведення негайних і системних заходів. Невід'ємною частиною цього процесу $\epsilon$ процедури сертифікації нових систем перед їх безпосереднім впровадженням у постійну експлуатацію. Це пов'язано з використанням принципово іншої елементної бази нових систем і використанням нових методів убезпечення їх функціонування.

3 введенням у дію нормативного документа ДСТУ 4178-2003 наприкінці минулого сторіччя фактично було створено підгрунтя для проведення процедури сертифікації нової техніки. Цей документ ознаменував початок переходу від застарілої концепції
\end{abstract}

«абсолютної» безпеки до нових підходів, які базуються на приймальному рівні ризику. На сьогодні деякі положення вказаного документа $є$ дещо застарілими, про що свідчать сучасні дослідження 3 теорії безпеки $[1,2,16]$. Крім того, набутий досвід 3 випробувань систем залізничної автоматики та доказу їхньої функційної безпеки вказують на необхідність розширення та удосконалення нормативнорегламентуючої бази.

\begin{tabular}{l}
\hline Аналіз досліджень \\
\hline \multicolumn{4}{c}{ Автори, базуючись на власному досвіді, вказують } \\
на необхідність удосконалення та розширення методів \\
випробувань програмного забезпечення залізничних \\
систем критичного призначення. Всі зазначені \\
дослідження корелюються зі стандартизованими \\
методами аналізу та розрахунків [8, 9]. Випробування \\
приладів і систем залізничної автоматики (у \\
подальшому об’єктів випробувань, ОВ), які \\
здійснюють функції керування та регулювання руху \\
поїдів, є достатньо актуальним та одночасно \\
складним технічним завданням, актуальність якого \\
задачі полягає в тому, що відповідність і якість \\
випробуваних ОВ безпосередньо пов'язана зі \\
збереженням здоров’я та життя людей, а складність \\
полягає в тому, що разом із традиційними \\
випробуваннями, результати яких можна отримати за \\
допомогою вимірювань, необхідно оцінювати такі
\end{tabular}


параметри, як функційна безпечність і надійність (ФБ, Н). Ці поняття визначені в чинному нормативному документі ДСТУ 4178-2003 [8]. Там пропонується на кожному етапі життєвого циклу ОВ, починаючи 3 етапу формування технічних вимог, експертувати i підтверджувати відповідність технічних і проектних рішень вимогам ФБ, Н. Рівень цих вимог, визначений у роботі [8], є надзвичайно високим - до $0,14 \times 10^{-10}$ небезпечної відмови за одну годину. Одним 3 найважливіших документів, на підставі якого згідно з роботою [8] оцінюється рівень ФБ, Н, є так званий «Доказ функційної безпечності», який формує та надає розробник ОВ, а експертує випробувач (акредитована випробувальна лабораторія). На допомогу розробникам (i випробувачам) існує галузева залізнична «Методика доказу функційної безпечності мікроелектронних комплексів систем керування та регулювання руху поїздів» [9] (у подальшому методика). Однак існують певні негативні особливості зазначених документів, які будуть розглянуті нижче, що суттєво ускладнюють формування експертних оцінок і суб' єктивізують підсумки експертиз. Методи локалізації розглянуто в роботі [10]. Однак значний обсяг досліджень виявив наявність двох основних нормативних документів, що регламентують забезпечення галузі оцінювання надійності та безпечних відмов $[8,9]$.

Мета статті й постановка досліджень полягає в тому, щоб дослідити особливості робіт [8], [9] і сформувати пропозиції, які б усунули виявлені недоліки.

\begin{tabular}{l}
\hline Основний текст статті \\
\hline Особливості ДСТУ 4178-2003 \\
Серед негативних особливостей роботи [8] треба в \\
першу чергу відзначити проблеми термінології. \\
Зокрема в назві та тексті здебільшого використаний \\
термін «комплекси технічних засобів (КТЗ)», який не є \\
безсумнівним у контексті розгляданого питання. По- \\
перше, КТЗ є тільки частиною відповідної системи \\
керування та регулювання. Кінцевого споживача \\
(підприємства АТ «Укрзалізниця») в першу чергу буде \\
цікавити ФБ всієї системи, та аж ніяк не ії частини, \\
навіть важливої, якою є КТЗ. Тому більш доцільним \\
можна вважати термін «Системи керування та \\
регулювання руху поїздів», згаданий у початковому \\
реченні ([8], сфера застосування, перший абзац). Але \\
це поняття потребує визначення іншого терміна - \\
об'єкт керування (ОК). Слід зауважити, що текст [8] не \\
містить визначення такого понятт. Також не \\
зазначено, що ОК є складовою частиною КТЗ. Такий \\
підхід призводить до виникнення певної \\
неоднозначності та суб’єктивних оцінок під час \\
оцінювання ФБ, Н. \\
Існує ще одна негативна особливість щодо \\
застосування поняття КТЗ. Кожний КТЗ містить дві \\
\hline
\end{tabular}

основні великі складові. Перша 3 них, а саме програмно-технічні комплекси, $€$ достатньо універсальними та не відображують суттєво специфіку конкретного ОК. Другі ж складові, навпаки, є цілком специфікованими та прив'язаними до конкретного об'єкта. Термін КТЗ у різних галузях промисловості використовується в сенсі суто першої - універсальної - частини. Тому цей термін може бути сприйнятий (використаний - i використовується у практиці) як спроба підмінити ціле (конкретну систему) універсальною i не прив'язаною до конкретного об'єкта частиною (КТЗ). Щодо зазначеного вище використання у практиці, то розробник засвідчує в той чи інший спосіб відповідність універсального КТЗ загальним вимогам нормативних документів без специфіки вимог конкретного ОК (конкретних ОК) i надалі намагається розповсюдити отримані результати на наступні конкретні ОК. Замовник у сфері залізничного транспорту у свою чергу не має бажання відокремлювати систему керування від ОК залізничної інфраструктури. Більш того, він, як правило, наполягає на включенні об'єкта до складу системи. Виникає певна колізія, яка полягає у наступному. Існуючі об'єкти залізничної інфраструктури, як правило, є давнішньої розробки. Відповідні показники надійності не набули масового розповсюдження, але вони точно не можуть відповідати сучасному рівню вимог ФБ, Н. Тому доказ функційної безпечності системи керування та регулювання руху поїздів, яка містить зазначені вище об'єкти залізничної інфраструктури, є досить проблематичним.

Слід відзначити і більш «дрібні» похибки термінології, використаної в роботі [8]. Зокрема там використані такі спірні поняття:

- «3.2.10 дестабілізівний чинник КТЗ. Чинник, у результаті дії якого може порушитися працездатний стан КТЗ.»;

- «справний стан» у 3.2.13: «3.2.13 стійкість КТЗ до впливу небезпечних дестабілізівних чинників. Властивість КТЗ зберігати справний, працездатний чи захисний стан, коли на нього діють дестабілізівні чинники.»;

- не визначені у розділі 3 щодо їхнього співвідношення 3 визначеними поняттяи «небезпечний стан», «безпечний стан», «захисний стан», а також «відповідальна функція» у 6.2.3, «технологічний алгоритм».

Визначення терміна «наробіток до небезпечної відмови...» у 3.2.21 не $\epsilon$ тотожним 3 аналогічним терміном у інших галузях «3.2.21 наробіток до небезпечної відмови КТЗ. Наробіток КТЗ від початку його експлуатації до виникнення першої небезпечної відмови».

Там ідеться про невідновлювані об'єкти, для яких перша відмова $є$ єдиною і останньою. Як бачимо, у 
терміні, зазначеному у 3.2.21, йдеться про першу відмову відновлюваного об' єкта.

У 7.6, А5 роботи [8] йдеться про закон розподілу кількості відмов. Цей закон названий експоненціальним, що $є$ помилкою. Відомо, що кількість відмов є дискретною випадковою величиною [11]. Відомо також 3 роботи [11], що послідовність часу між відмовами $є$ безперервною випадковою величиною та підпорядковується експоненційному закону. Але у 7.6, А5 не йдеться про розподіл часу, а йдеться саме про розподіл відмов, тобто їхньої кількості.

У 7.7 йдеться про експоненційний закон розподілу між відмовами, але не вказано, про яку саме випадкову величину йдеться, імовірно, пропущено слово «часу» після слова «розподілу».

Існують певні неоднозначні технічні норми. Зокрема наведені у роботі [8] п. 6.2.3 (таблиця 1) нормативи $\epsilon$ занадто високими, ультимативними i технічно необгрунтованими. Обгрунтування цього твердження буде наведено нижче. Крім того, назва та зміст розд. $11 €$ дещо застарілими щодо чинних сьогодні вимог електромагнітної сумісності. Зокрема наявні вимоги розд. 11 стосуються тільки захищеності технічних засобів від електромагнітних завад, але цілком відсутні вимоги до цих технічних засобів як можливих джерел продукування електромагнітних завад.

Необхідно також відзначити й певні особливості роботи [8], які ускладнюють розрахунок параметрів надійності ОК. 3 роботи [12] відомо, що ці розрахунки базуються на отриманні та обробці інтенсивностей відмов комплектувальних елементів, які у 14.7 аналізованого нормативного документа пропонується визначати за довідниками. Конкретні приклади таких довідників не наведені. Натомість пропонується отримувати їх від підприємств-виробників, з технічної документації, довідників (які знову конкретно не зазначаються). При всій формальній коректності таких пропозицій слід зазначити, що вітчизняна реальність у цій царині така, що такі пропозиції практично неможливо зреалізувати.

Для розуміння цього факту доцільно згадати, як така система працювала за часів СРСР. Існувала певна кількість вітчизняних виробників великих обсягів електрорадіоелементів. Ці радіоелементи широко застосовувалися вітчизняною промисловістю тих часів. Рекламації, а також інші документи щодо відмов застосованих електрорадіоелементів ретельно збиралися виробниками. Ця інформація піддавалася статистичній обробці. У підсумку формувалися відповідні довідники (часто-густо 3 обмеженим доступом), які містили необхідні інтенсивності відмов. Для здійснення цієї роботи на підприємствах існували спеціальні структурні підрозділи.
Вітчизняна реальність $є$ такою: потужні виробники електрорадіоелементів фактично відсутні, статистичні дані не збираються і не обробляються. Вітчизняні розробники, у т. ч. розробники КТЗ, змушені користуватися імпортованими компонентами, для яких фактично неможливо отримати дані щодо їхньої надійності. 3 міркувань мінімізації вартості КТЗ виробниками здебільшого застосовуються найбільш дешеві компоненти.

Пропозиції роботи [8] доцільно застосовувати для розрахунків вірогідності відмов (небезпечних відмов), оскільки дані технічної документації або довідників не $\epsilon$ коректними. У випадку застосування даних часів СРСР отримуємо КТЗ фатально низьких значень ФБ, Н через низьку довідкову надійність радянських електрорадіоелементів.

Певним виходом $\epsilon$ застосування доступних закордонних довідників, зокрема [13]. Однак цей довідник розрахований на використання даних здебільшого елементів американського militaryстандарту, які $є$ недосяжними для більшості вітчизняних розробників, як мінімум, 3 економічних міркувань. У випадку застосування даних з роботи [13] для розрахунків отримаємо суттєво кращі показники ФБ, $\mathrm{H}$.

Всі зазначені вище негативні особливості роботи [8] суттєво знижують цінність цього нормативного документа.

Особливості методики доказу функиійної безпечності мікроелектронних комплексів систем керування та регулювання руху поїздів

Перевірка розрахунків щодо кількісних показників ФБ, Н пов'язана 3 інженерними обчисленнями дуже малих чисел. Відповідні розрахункові співвідношення наводяться в галузевому залізничному документі «Методика доказу функційної безпечності мікроелектронних комплексів систем керування та регулювання руху поїздів» [9] (у подальшому методика), яка містить певні сумнівні допущення та висновки. Зокрема твердження 4.1.1 методики, що мікроелектронні елементи $є$ менш безпечними, ніж електромагнітні реле першого класу надійності, $€$ безпідставним i потребує обгрунтування. Останні мають норму $10^{6}$ спрацювань під повним електричним навантаженням, що $є$ на декілька порядків гіршим за вимоги ФБ, Н до цілих систем. Розрахункова формула 5.20 [9]:

$Q_{H}(t)=1-P_{\sigma}(t)=1-e^{-\lambda t}=1-\left[1-\frac{\lambda t}{1 !}+\frac{(\lambda t)^{2}}{2 !}-\frac{(\lambda t)^{3}}{3 !}+\ldots\right] \approx \lambda t$

базується на припущенні, що для значення інтенсивності відмов системи $\lambda$ за час $t$ для високонадійних систем справедливе співвідношення 
$\lambda t \pi 0,1$. Це не є очевидним, зокрема для випробувань 3 тривалим $t$. Однак під час підрахунку показників, пов'язаних 3 періодом часу $t=1$, таке припущення $\epsilon$ цілком прийнятним. Безперечним доказом високої надійності системи $є \lambda \pi 1$. У реальності для аналізованого класу систем $\lambda \approx 10^{-11}$. Формула (5.20) методики щодо ймовірності небезпечної відмови $Q_{H}(t) \approx \lambda t$ суттєво спрощує обчислення. Однак похибка обчислень за цією формулою, зважаючи на запропонований характер спрощення, гарантовано надасть приблизний результат більш оптимістичним, ніж відповідний точний підрахунок. Крім того, у роботі [12] не оцінена похибка розрахунку за формулою 5.20, враховуючи різноманітність умов іiі використання (різні значення t). Все це може суттєво вплинути на результати розрахунків.

Пропозииії щзодо подальшого розвитку нормативних документів аналізу функціональної безпечності мікроелектронних комплексів систем керування та регулювання руху поїдів

Усунення термінологічних розбіжностей роботи [8] в цілому $є$ достатньо простим завданням. Треба здійснити одне 3 двох: користуватися в тексті виключно термінами, визначеними в розд. 3, вилучивши зайві терміни, або додатково визначити не визначені раніше терміни, без застосування яких неможливо обійтися. Ще простіше надати первинне тлумачення застосованим скороченням.

Щодо застосування терміна КТЗ, то доцільно замінити його на запропоноване вище «системи керування та регулювання руху поїздів» 3 можливим подальшим коректним скороченням, наприклад СКРРП. Також слід паралельно ввести поняття «об' єкт керування $(\mathrm{OK}) »$ (або ідентичне за сутністю) з точним і конкретним визначенням межі, що стосується ОК, а що СКРРП.

Коректно назвати закон розподілу дискретної випадкової величини (кількість відмов) пуасонівським, а наробіток відновлюваної системи змінити 3 «до відмови» на «на відмову».

Треба зробити певні уточнення щодо терміна «...на одну відповідальну функцію», який застосований у п.6.2.3. Як було відзначено вище, цей термін не $є$ визначеним у роботі [8]. Однак у залізничній галузі впроваджений і використовується термін «відповідальні команди (ВК)», наприклад у роботі [14], яка визначається як така, що здійснюється під відповідальність посадової особи. У цьому випадку функціональна безпечність ВК контролюється не автоматикою системи диспетчерської централізації, а саме посадовою особою, яка цю команду здійснює. У режимі видачі ВК спрацювання пристроїв контролюючої безпеку автоматики не передбачається. Надалі розглянемо приклад. Припустимо, що в якості
ОК маємо систему диспетчерської централізації в режимі видачі окремої ВК, що й маємо право вважати відповідальною функцією. 3 цього прикладу стає зрозумілим, що вимога автоматичного контролювання функційної безпечності відповідальної функції, безпеку якої в розглянутому прикладі контролює тільки посадова особа, є некоректною. Виходом 3 цієї колізії могла б стати примітка щодо виключення вимог ФБ до функцій, безпека яких контролюється людиною або вилучення терміна «відповідальна функція» 3 тексту роботи [8].

Що стосується розд. 11 [8] (вимоги функційної безпечності технічних засобів у разі дії електромагнітних завад), то його доцільно доповнити посиланнями на норми діючих міжнародних стандартів щодо електромагнітної сумісності, які б містили не тільки норми стійкості ОВ [15] до дії електромагнітних завад, але й норми емісії електромагнітних завад з боку ОВ.

Що стосується методики [12], то вона, не зважаючи на певні недоліки, які були розглянуті раніше, може бути основою для розрахунків значень показників ФБ, Н. Покладемо у формулі (5.20) [9] цієї методики $t=1$. Тоді ймовірність відмови (у т. ч. небезпечної відмови) за одну годину

$Q_{H}(1) \approx \lambda$

Ця проста приблизна формула може слугувати основою для розрахунків ФБ, Н систем керування та регулювання руху поїздів і їхніх компонентів.

Багатьох недоліків роботи [8] можна було б уникнути, застосовуючи більш прогресивні стандарти 3 серії IEC 61508 «Функціональна безпечність електричних /електронних/ програмованих електронних систем, пов'язаних 3 безпекою». Зазначена серія містить сім частин (частково впроваджені в Україні) і використовується в странах $€ C$, зокрема для оцінювання ФБ, Н систем залізничної автоматики. Характерні ознаки пропонованих нормативних документів: там менше прямих заборон, більше конкретних рекомендацій для розробників i більш лояльні (на декілька порядків) порівняно 3 роботю [8] норми показників ФБ, Н, що може бути обгрунтуванням нереальності останніх. Крім того, розповсюдження набуло докладне керівництво 3 застосування зазначеної серії стандартів [16], що суттєво спрощує користування ними. Зокрема щодо пропонованої філософії вбудованих систем контролювання для найвищого (четвертого) рівня безпеки, то вона суттєво відрізняється від філософії побудови таких систем, що застосовуються вітчизняними розробниками засобів автоматики для потреб залізниці. В Україні розповсюджена двоканальна структура 3 рівноправними каналами та 
перехресним контролюванням (рис. 1). Тобто обидва високонадійні канали синхронно виконують одну й ту саму програму, при цьому другий канал контролює вихідні сигнали першого i, навпаки, перший канал контролює вихідні сигнали другого.

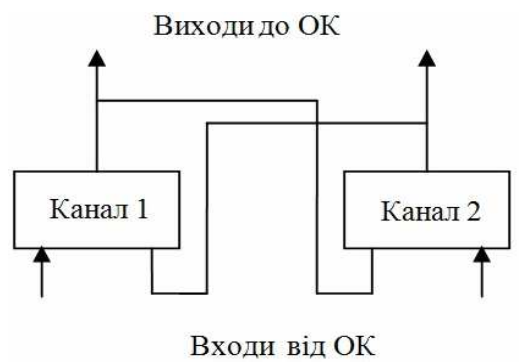

Рис. 1. Структура двоканальної схеми

При виявленні неспівпадіння контрольованої інформації система переводиться в режим захисної відмови. У розглянутій структурі можливі чотири стани (табл. 1). Будемо вважати можливі відмови каналів незалежними подіями 3 вірогідностями згідно 3 формулою (1)

$Q_{1}=Q_{2} \approx \lambda$.

Тоді, беручи до уваги формулу (2), вірогідність відмови обох каналів буде

$Q_{3}=Q_{2} \times Q_{2} \approx \lambda^{2}$.

Значення формули (3) буде занадто малим - ним у подальших розрахунках можна знехтувати. Надалі розглянемо випадок відмови одного довільного каналу. Хибне значення виходу цього каналу (або хибне значення результатів контролю виходу іншого каналу) призведе до вмикання режиму відмови, яка є захисною. Загальна вірогідність події, що містить події 2 та 3 таб. 1, буде

$Q_{1,2}=Q_{2}+Q_{3} \approx 2 \lambda$.

Таким чином, беручи до уваги формулу (4), можна вважати, що за рахунок введення другого каналу в структуру рис. 1 iï надійність погіршилася у два рази, зате маємо відсутність можливої небезпечної відмови за умов відмови одного довільного каналу.

Зокрема у роботі [16] запропонована суттєво інша побудова надійної системи: канал контролювання не $є$ аналогічним основному каналу, не дублює його функцій основного; зв'язок між основним і контролюючим каналами має бути мінімальним. Зазначений принцип побудови може слугувати основою для розробників і суттєво спростити процеси випробувань.
Таблиця 1

Перелік станів двоканальної системи

\begin{tabular}{|c|c|l|}
\hline $\begin{array}{c}\text { Номер } \\
\text { стану }\end{array}$ & $\begin{array}{c}\text { Позначення } \\
\text { вірогідності стану }\end{array}$ & \multicolumn{1}{|c|}{ Опис стану } \\
\hline 1 & $Q_{0}$ & $\begin{array}{l}\text { Обидва канали } \\
\text { працездатні }\end{array}$ \\
\hline 2 & $Q_{1}$ & Відмова каналу 1 \\
\hline 3 & $Q_{2}$ & Відмова каналу 2 \\
\hline 4 & $Q_{3}$ & Відмова каналів 1 і 2 \\
\hline
\end{tabular}

\section{Висновки}

Таким чином, мету дослідження можна вважати досягнутою. Виявлено певні термінологічні та технічні особливості нормативного документа ДСТУ 41782003, які суттєво ускладнюють і суб'єктивізують процес випробувань комплексів технічних засобів систем керування рухом поїздів. Сформульовано пропозиції, які б у разі їх, застосування змогли б усунути ці негативні особливості. Проаналізовано особливості розрахунку показників функційної безпеки та надійності за допомогою відомчої методики доказу функційної безпечності мікроелектронних комплексів систем керування та регулювання руху поїздів та особливості побудови систем 3 розповсюдженою двоканальною структурою. Надано рекомендації, співвідношення, розрахункові формули. Зокрема відзначено актуальність застосування нових нормативних документів серії IEC 61508 й рекомендується усунути зазначені недоліки.

\section{Список використаних джерел}

1. Мойсеєнко В. І., Самсонкін В. М. Теорія безпеки на залізничному тран-спорті: монографія. Київ: Каравела, 2014. 248 с.

2. Мойсеєнко В. І., Бутенко В. М. Безпечність спеціалізованих комп'ютерних систем: навч. посіб. Харків: УкрДУЗТ, 2020. 112 с.

3. Павленко Е. П., Бутенко В. М., Губин В. А. Исследование методов разка-ботки программного обеспечения информационных систем на основе типовых программных элементов. Вісник Національного технічного університету «ХПІ». Cep. Системний аналіз, управління та інформаційні технології: зб. наук. праць. Харків: НТУ «ХПІ», 2018. № 44 (1320). С. 11-15.

4. Чумаченко О. В., Суліма С. А. Оцінка програмного забезпечення систем залізничного транспорту станційного рівня на відповідність вимогам українських стандартів. Інформ.-кер. сист. на залізнич. тр-ті: наук.-техн. журнал. Харків: УкрДУЗТ, 2020. № 1. С. 34-40.

5. Кількісний аналіз показників надійності систем автоматики 3 використанням моделювання дерев 
небезпечних відмов / В. М. Бутенко, Д. О. Зубрицький, С. В. Сіроштан, С. С. Строєв. 3б. наук. працьь. Харків: УкрДАЗТ, 2008. Вип. 92. С. $133-138$.

6. Моделирование состояний объектов систем железнодорожной автоматики / В. Й. Поддубняк, С. А. Радковский, В. М. Бутенко, В. И. Мойсеєнко. Информащионно-управляюшие системь на железнодорожном транспорте. 2001. №4 C. 40-44.

7. Определение технического состояния объектов железнодорожной автоматики с применением теории нечетких множеств / В. Й. Поддубняк, С. А. Радковский, В. М. Бутенко, В. И. Мойсеєнко. Информационно-управляюшие системы на железнодорожном транспорте. 2001. №6 C. $35-37$.

8. ДСТУ 4178-2003. Комплекси технічних засобів систем керування та регулювання руху поїздів. Функційна безпечність і надійність. Вимоги та методи випробування. Каталог нормативних документів. Київ: Держспоживстандарт України, 2003 DSTU 4178-2003. 73 c.

9. Методика доказу функціональної безпечності мікроелектронних комплексів систем керування та регулювання руху поїздів. Київ: Міністерство транспорту України. Державна адміністрація залізничного транспорту України, 2002. 98 с.

10. Мойсеєнко В. І. Локалізація небезпечних подій процессу використання засобів залізничного транспорту: 3б. наук. працьь Укр. держ. акад. залізнич. трансп. Харків: УкрДАЗТ, 2010. Вип. 114. С. 22-24.

11. Бешелев О. Д., Гуревич Ф. Г. Математикостатистические методы експертных оценок. Москва: Статистика, 1980. 263 с.

12. Надежность изделий электронной техники для устройств народнохозяйственного назначения: справочник. Москва: Всесоюзный научноисследовательский інститут «Электростандарт», $1989.188 \mathrm{c}$.

13. MIL-HDBK-217F. Military handbook "Reliability prediction of electronic equipment", Notice 1, 1991. $900 \mathrm{c}$.

14. ГОСТ Р 54899-2012. Системы диспетчерской централизации и диспетчерского контроля движения поездов. Требования безопасности и методы контроля. Москва: Стандартинформ, 2012. $23 \mathrm{c.}$

15. ДСТУ 4151-2003. Комплекси технічних засобів систем управління та регулювання руху поїздів. Електромагнітна сумісність. Вимоги та методи випробувань. Каталог нормативних документів. Київ: Держспоживстандарт України, 2003. 15 с.

16. Смит Дэвид Дж., Симпсон Кеннет Дж.. Функциональная безопасность. Простое руководство по применению стандарта МЭК 61508 и связанных с ним стандартов. Москва:

Издательский Дом «Технологии», 2004. 208 с.

Mojseenko V. I., Butenko V. M., Chub S. G., Golovko O. V. Problems of testing a complex of train traffic control and regulation technical means.

Abstract. This article is devoted to the study of the problems that arise during the testing of technical means complexes for train traffic control and regulation. In particular, the importance and complexity of assessing the indicators of functional safety and reliability, as well as the high level of current requirements, were noted. Analyzed the content of the normative document DSTU 4178-2003, which defines the requirements for this indicators, as well as the document "Methodology for proving the functional safety of microelectronic complexes of control and regulation systems for train traffic" (hereinafter "Methodology"), which defines the method for calculating these indicators, as well as the methodology for their assessment. Also analyzed the historical prerequisites for the formation of just such an approach to the definition of both the object of assessment and the methodology for assessing functional safety. The terminology used in this DSTU was reviewed for compliance with real objects of the traffic control system for which functional safety is determined. It is noted that it is important to take into account the influence of the human factor in the process of their operation when assessing the functional safety of the considered systems. The inaccuracies in the definition of both the objects of research themselves and the states in which these objects can arrive are indicated. The document "Methodology" revealed certain inaccuracies in determining the conditions under which the functional safety assessment takes place. These negative features of the above documents significantly complicate the formation of objective expert assessments. Proposals are formulated to eliminate these negatives, in particular, the improvement of existing regulatory documents or the transition to the use of new ones.

Keywords: Functional safety, traffic control systems, control object, tests, reliability.

Мойсеенко В. И., Бутенко В. М., Чуб С. Г., Головко А. В. Проблемы испытаний комплекса технических средств управления и регулирования движения поездов.

Аннотация. Данная статья посвящена исследованию проблем, которые возникают во время испытаний комплексов технических средств управления и регулирования движением поездов. В частности отмечены важность и сложность оценки показателей функциональной безопасности и надежности, а также высокий уровень существующих на данный момент 
І Н Ф О Р М А Ц Й Н О - КЕ Р У Ю Ч І С И С Т Е МИ Н А З А Л І З Н И Ч Н О М У Т Р А Н С П О Р Т І

требований. Проанализировано содержание нормативного документа ДСТУ 4178-2003, в котором определены требования к указанным показателем, а также документа «Методика доказательства функциональной безопасности микроэлектронных комплексов систем управления и регулирования движения поездов» (дальше Методика), в котором и определены методика вычисления данных показателей, а также методика их оценки. Проанализированы исторические предпосылки формирования именно такого подхода к определению как объекта оценки, так и методики оценки функциональной безопасности.

Ключевые слова: испытания, функциональная безопасность, надежность.

Надійшла 04.09.2020 p.
Chub Sergii G., PhD, Associate Professor, SE "Kharkivstandartmetrologiia", Kharkiv, Ukraine. E-mail: chub.3.6.49@gmail.com http://orcid.org/0000-00024375-4676

Golovko Oleksandra V., PhD, Associate Professor department of Computer Engineering and Control Systems, Ukrainian State University of Railway Transport, Kharkiv, Ukraine. E-mail: golovko@kart.edu.ua http:// orcid.org/0000-0002-9880-428X

Мойсеснко Валентин Іванович, доктор технічних наук, завідувач кафедри спечіалізованих комп'ютерних систем, Український державний університет залізничного транспорту, Харків, Україна, 61050. E-mail: mojseenko@kart.edu.ua http://orcid.org/0000$\underline{0003-1377-8703}$

Бутенко Володимир Михайлович, кандидат технічних наук, доцент кафедри «Спеціалізовані комп'ютерні системи», Украӥнський державний університет залізничного транспорту, Харків, Україна. E-mail: http://orcid.org/0000-0001-9958-3960

Чуб Сергій Григорович, кандидат технічних наук, доиент, провідний інженер ДП «ХавківСтандартМетрологія», Харків, Україна. E-mail: chub.3.6.49@gmail.com http://orcid.org/00000002-4375-4676

Головко Олександра Володимирівна, кандидат технічних наук, дочент кафедри «Обчислювальної техніки та систем управління», Украӥнський державний університет залізничного транспорту, Харків, Україна. E-mail: golovko@kart.edu.ua http:// orcid.org/0000-0002-9880-428X

Moiseenko Valentin I., Doctor, Professor department of specialized computer systems, Ukrainian State University of Railway Transport, Kharkiv, Ukraine. E-mail: mojseenko@kart.edu.ua http://orcid.org/0000-00031377-8703

Butenko Volodymyr M., PhD, Associate Professor department of specialized computer systems, Ukrainian State University of Railway Transport, Kharkiv, Ukraine. E-mail: butenko@kart.edu.ua http://orcid.org/0000$\underline{0001-9958-3960}$ 